\title{
Giant Cell Tumor of the Talus: A case report and review of literature
}

\author{
by Arunangsu Bhattacharyya,MS[Ortho $]^{1} \Xi$, Rana Das,MS[Ortho $]^{2} \rrbracket$, \\ Rajesh Darwani,D.[Ortho] $]^{3} \square$
}

The Foot and Ankle Online Journal 3 (8): 2

Giant cell tumor is described as neoplasm of undifferentiated mesenchymal stromal cells with presence of abundant, multi-nucleated giant cells. It is basically a benign aggressive tumor which involves the epiphyseometaphyseal end of long bones. Giant cell tumor rarely involves small bones of hand and foot, and is a rare finding within the talus. In the case report, a patient complains of pain and swelling over the left ankle for one year. Plain radiographs and computerized tomography scan (CT) and CT guided fine needle aspiration cytology suggested a diagnosis of giant cell tumor. The tumor was of grade I according to Campanacci grading and there was not cortical break. Treatment consisted of intralesional curettage and an autogenous cancellous bone graft. After two years follow-up, the patient was able to walk with full weight bearing on the affected limb without pain. There were no signs of recurrence both clinically or radiographically.

Key words: Giant cell tumor, talus, fine needle aspiration cytology, Campanacci grading, intralesionsal currettage

Accepted: July, $2010 \quad$ Published: August, 2010

This is an Open Access article distributed under the terms of the Creative Commons Attribution License. It permits unrestricted use, distribution, and reproduction in any medium, provided the original work is properly cited. (The Foot and Ankle Online Journal (www.faoj.org)

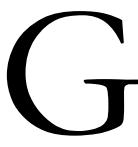
iant cell tumor is described as neoplasm of undifferentiated mesenchymal stromal cells with the presence of abundant, multinucleated giant cells. The tumor typically involves the epiphyseo-metephyseal region of long bones and is usually expansile and eccentric in position.

Address correspondence to: Dr Arunangsu Bhattacharyya,MS(ORTHO) A-8/4,Bidhan Abasan,Block-FB,Sector-3,Saltlake,Kolkata-700097.West Bengal,India. Email: orthoarunangsu@yahoo.com

${ }^{1}$ Assistant Professor,Dept. of orthopaedics, Medical college, Kolkata.

${ }^{2}$ Assocate Professor, Dept. of orthopaedics, Medical college, Kolkata.

${ }^{3}$ Senior resident, Dept. of orthopaedics, Medical college, Kolkata.

There is no conflict of interest or source of support to report with this article.
In 1912, Bloodgood named the tumor as a benign, "giant cell tumor". Whilst Jaffe and associates in 1940 agreed with Bloodgood that the tumor was benign, they stated that it was locally aggressive. ${ }^{2}$ Strangely, the tumor is primarily malignant or it metastasizes or undergoes malignant transformation in only three percent of cases. ${ }^{3}$

Giant cells in histopathology are also commonly found in other lesions, the so-called variants of giant cell tumors. These lesions include non-ossifying fibroma, unicameral bone cyst, localized osteitis fibrosa, aneurysmal bone cyst, chondromyxoid fibroma, benign chondroblastoma and the "brown tumor" of hyper parathyroidism. ${ }^{4}$ 


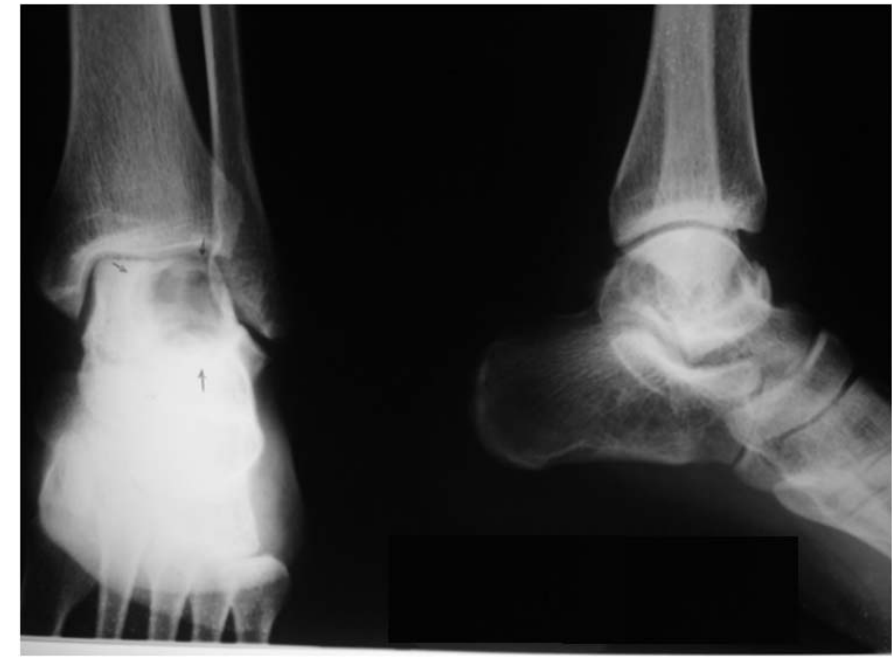

Figure 1 Pre-operative radiograph shows eccentric cystic lesion with intralesional septa within talus suggestive of giant cell tumor.

Giant cell tumor most commonly involves long bones around knee. The most common sites of the giant cell tumor are sequentially at distal end of femur, upper end of tibia and lower end of radius. ${ }^{5}$ Tumors involving tarsal bones are extremely rare. Most of these occur in talus and calcaneum. In contrast to lesions of long bones, they occur in early age group and are commonly multicentric. ${ }^{6}$

Few cases of giant cell tumors of the talus are reported in literature. ${ }^{6,7}$ Most of them were managed by total talectomy and tibiocalcaneal arthrodesis. ${ }^{7,8}$ Talectomy with arthrodesis however is associated with problems which include lower limb shortening, deranged longitudinal arch and an immobile ankle which can interfere with normal foot function.

Campanacci grading has been used for cortical breach in computed tomography (CT) and roentgenogram. A grade I tumor presents with a well marginated border of a thin rim of mature bone and intact or slightly thinned but not deformed cortex. A grade II tumor presents with well defined margins, but no radioopaque rim; whilst grade III tumors have fuzzy borders. ' Campanacci grades I and II are predominantly treated with curettage while grade III tumors are treated mostly with wide excision.

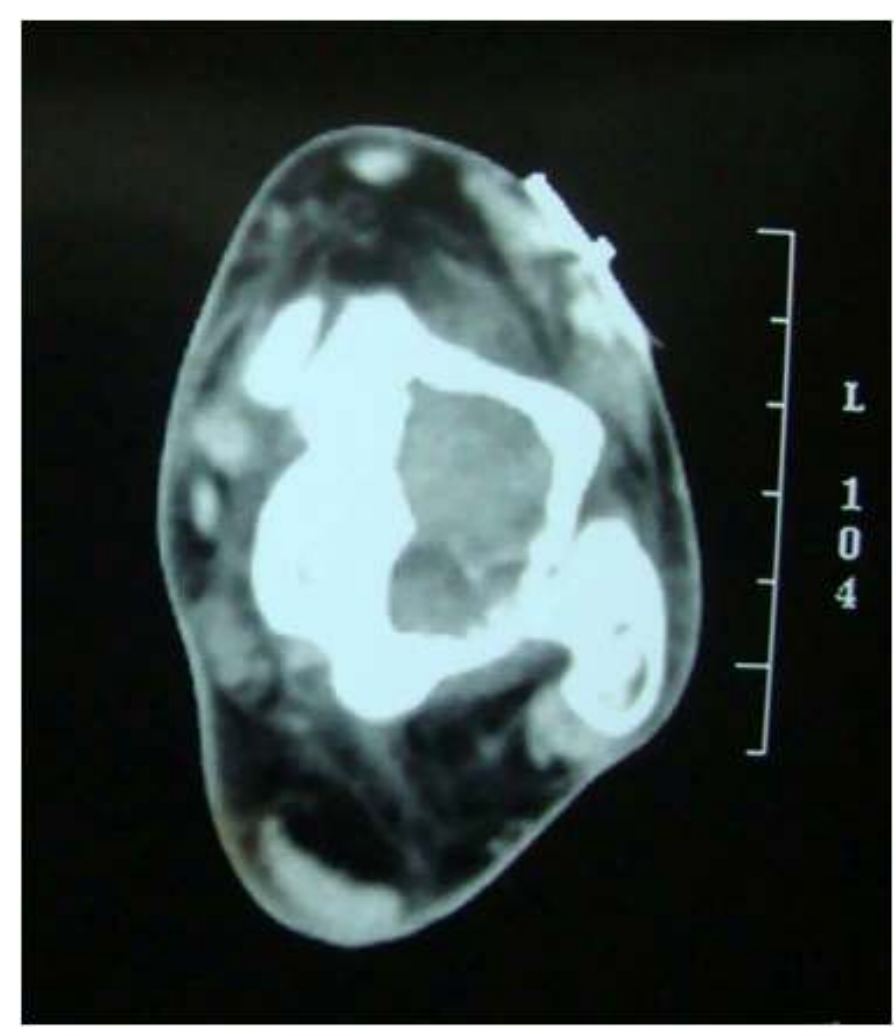

Figure 2 Pre-operative computed tomography scan shows lesion within talus with no cortical break.

This reported case was a grade I lesion according to Campanacci grading as the tumor was bordered by a thin, intact rim of cortex. A simple and less radical measure such as intralesional curettage and bone grafting, was opted for here. The treatment preserved the normal structural and biomechanical properties of the ankle joint.

\section{Case Report}

A 22 year-old male presented with pain in the right ankle for more than a year with limping on the affected side. The pain was described as a dull ache, poorly localized, initially only on walking, but increased gradually to persistent pain even at rest. There was no history of trauma or fever. Examination revealed mild swelling around the left ankle without any tenderness and no sign of inflammation or infection such as erythema, induration or local rise of temperature. 


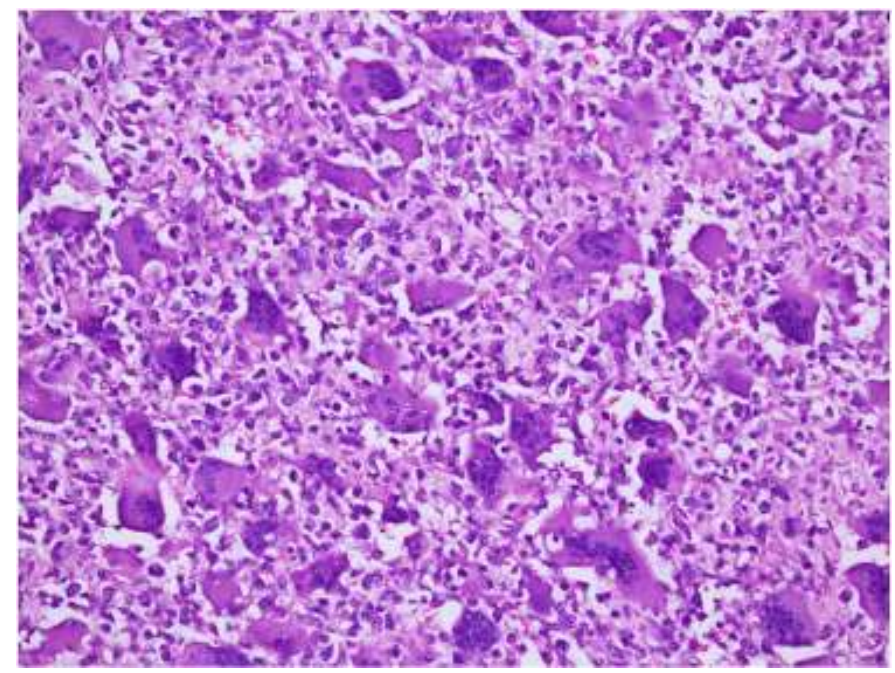

Figure 3 A giant cell rich tumor containing many osteoclastic giant cells and bland stromal cells; H\&E, X4 original magnification.

Ankle and subtalar movements were full and painless. Ethical committee permission was taken for this study (From which health board? State in brackets). Informed consent was secured from the patient.

Routine blood investigations were within normal limits including erythrocyte sedimentation rate and creative reactive protein. Plain radiographs showed a geographic osteolytic lesion in the body of talus with narrow zone of transition and no cortical break. (Fig. 1) It was characterized as a grade I lesion according to Campanacci grading for cortical breach. ${ }^{9}$

CT scan of the ankle re-established the radiographic findings of a well contained lesion within the Talus. (Fig. 2) CT guided fine needle aspiration cytology report was suggestive of giant cell tumor of grade I according to Campanacci, et al., ${ }^{10}$ Histological finding was a giant cell rich tumor containing many osteoclastic giant cells and bland stromal cells. (Fig.3) Since CT scan did not reveal a cortical breach, magnetic resonance imaging was not ordered.

General body survey and a chest radiograph were performed to rule out multicentric disease and pulmonary metastasis.

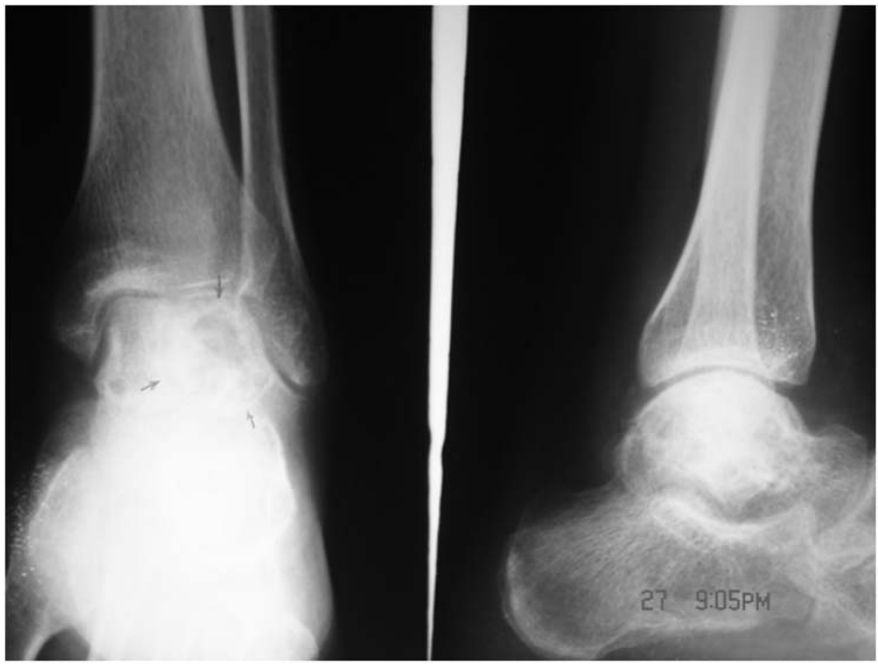

Figure 4 Radiograph after six months of surgery shows gradual incorporation of bone graft and obliteration of bone cavity.

As this tumor metastasizes or undergoes malignant transformation in only three percent of cases, medical therapy was not applied for prevention of metastasis. At the present time, recognized effective chemotherapeutic agents are also not available for the management of these tumors.

As the lesion was localized to the talus, thorough curettage and bone grafting was planned. Standard anterolateral incision was made to expose the talus. A cortical window was made in the lateral surface to enter the cyst. Reddish brown tumor material was curetted out. Chemical curettage was performed with phenol and the cavity was packed with autologous cancellous bone graft harvested from the ipsilateral iliac crest. The wound was closed in layers and a below knee plaster of paris (POP) back slab or splint was applied. Stitches were removed on the fourteenth day and non weight bearing crutch walking was started. Ankle movement was allowed. Walking over the affected heel was started after partial obliteration of the tumor cavity. The patient was followed up at every 15 days initially for first six months, then monthly for one year. After one year he was asked to attend follow-up clinic at every six months. (Fig. 4) 


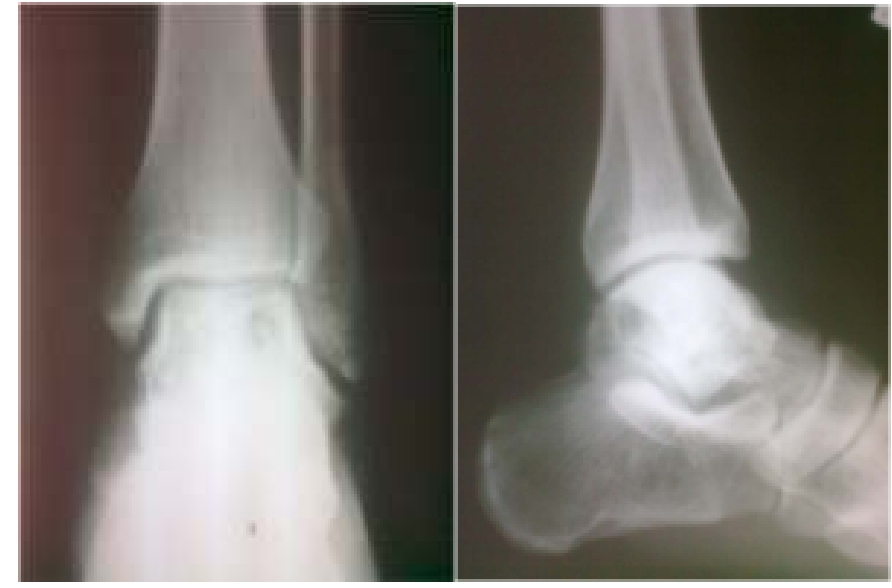

Figure 5 Radiograph after two years of surgery shows almost full obliteration of cyst within talus which helped to withstand load during walking.

The reported case was followed up with radiographs. After two years the tumor showed no signs of recurrence and bone cavity is almost filled up. (Fig. 5) The patient now walks with full weight bearing on the affected side and ankle and subtalar movements were full and painless. (Fig. 6)

\section{Discussion}

Giant cell tumors are very commonly encountered in clinical practice, but lesions involving talus are uncommon. The talus is a very unusual site for giant cell tumour and is a rare entity. Goldenberg, et al., in their series of 218 cases found only one case involving the talus. ${ }^{11}$ In the series of 208 cases by Sung, et al., one case has been reported. ${ }^{12}$ The locally aggressive nature of the lesion warrants proper assessment and planning for management. As lesions affecting small bones of hands and feet are often multicentric, a comprehensive investigation for other lesions is emphasised. ${ }^{6}$

Treatment options include intralesional curettage and bone grafting or talectomy with tibiocalcaneal arthrodesis. $8,13,14$

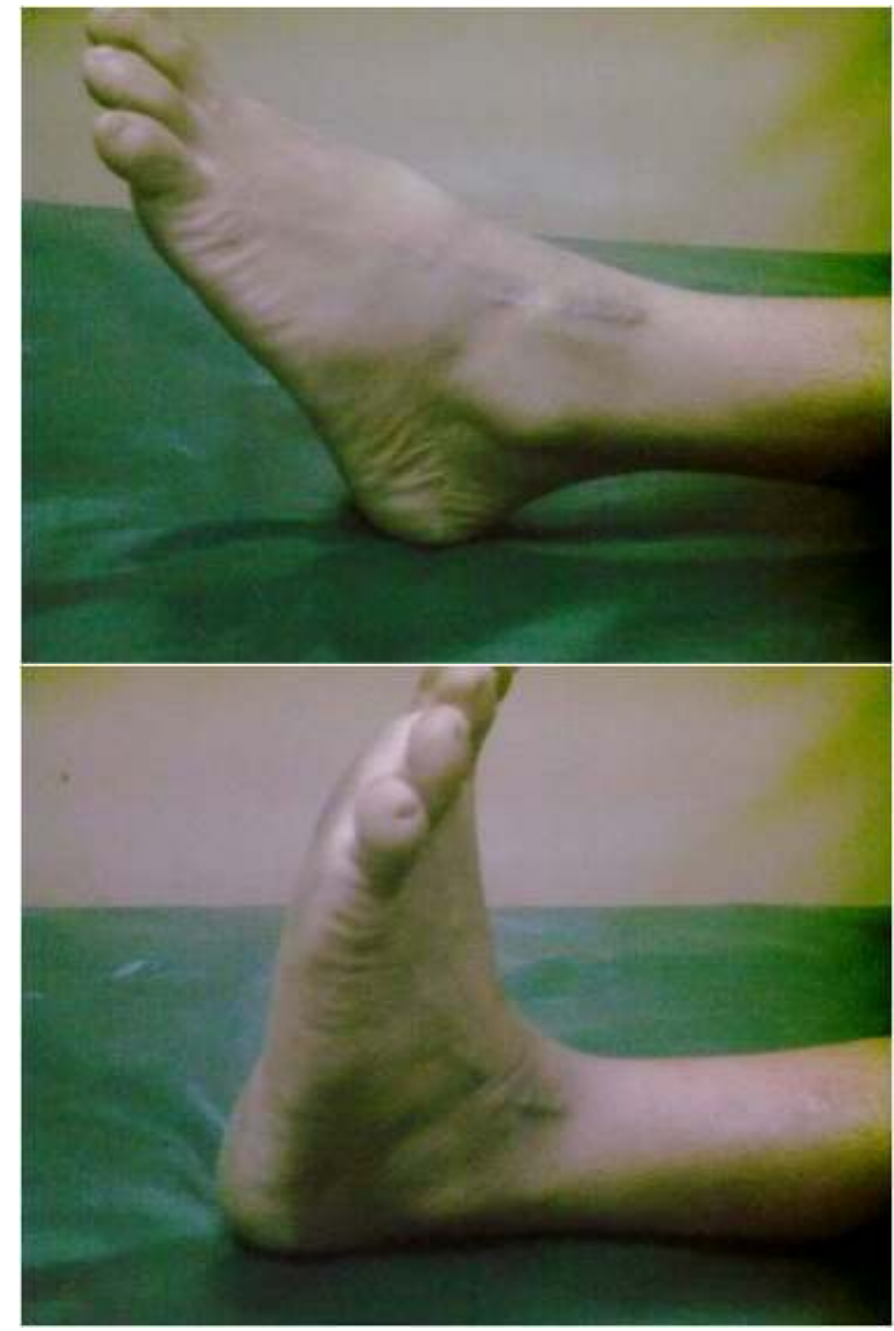

Figure 6 The operated ankle shows full range of plantarflexion and dorsiflexion at recent follow-up.

Talectomy with tibiocalcaneal arthrodesis is beneficial as it ensures complete removal of the tumor, but it is complicated by limb shortening, disturbed arches of foot and a stiff ankle causing functional limitation. In their case report, Sharma, et al., reported successful treatment of a talar giant cell tumor with talectomy and tibiocalcaneal arthrodesis. ${ }^{8}$ The lesion in their case, however, had led to extensive destruction of talus.

Malawer also reported two cases of giant cell tumorof the talus and suggested talectomy as the primary treatment. ${ }^{15}$ Dhillon, et al., reviewed 12 cases of talar tumors of which the giant cell is common, and suggested talectomy in the case of talar collapse. ${ }^{14}$ 
Another case was reported by Sayed, et al., where giant cell tumor of the talus was treated by intralesional curettage and autologous bone grafting and patient's pain and swelling disappeared. Complete range of movement at the ankle joint was regained with minimal restriction of movements at the subtalar joint. There was no evidence of recurrence at 6 months follow-up. ${ }^{16}$

In this case report, we also performed intralesional curettage and bone grafting with a good results and no recurrence. Since the lesion was well localized within the body of talus, only curettage, chemical cauterization and bone grafting was indicated. This proved to be a sufficient treatment. The bone cavity was filled at eight months and at one year the patient was walking without pain. It is to be emphasized that curettage with bone grafting alone may suffice only when the lesion is localized without a cortical breach. Extensive curettage with a sufficiently large cortical window and use of a power burr was performed in our case. Use of adjuvants in the form of phenol, liquid nitrogen or argon beam coagulation further ensures complete ablation of the tumor tissue.

In judiciously selected cases of giant cell tumor of the talus with the lesion well localized without a cortical break, properly performed extensive curettage and bone grafting can be a good option for complete removal of the tumor while preserving near normal structure and function of the ankle.

\section{Conclusion}

In giant cell tumors of the talus with a Campanacci grade I, intralesional extensive curettage and bone grafting still remains suitable treatment for tumors. It appears that a low rate of recurrence can be achieved if curettage and bone grafting is performed thoroughly and in properly selected cases. Assessment of the tumor with cross-sectional CT and a well planned surgical approach is necessary in attaining the best result.

\section{Acknowledgement}

We acknowledge our gratitude to the Principal of Medical College, Kolkata for allowing undertake this case report.

\section{References}

1. Bloodgood JC. Benign giant cell tumour of bone: Its diagnosis and conservative treatment. Am J Surg 1923 37:105116.

2. Jaffe HL, Lichtenstein L, Partis RB. Giant cell tumour of bone: Its pathological appearance, grading, supposed variants and treatment. Arch Path 1940 30: 993-1031.

3. Malawer MM, Bickels J, Meller I, Buch RG, Henshaw RM, Kollender Y. Cryosurgery in the treatment of giant cell tumor. A long-term followup study. Clin Orthop Rel Res 1999 359:176188.

4. Turek SL. Tumours of Bone. Orthopaedic Principles and their Applications. $4^{\text {th }}$ edition. Philadelphia, Lippincott, 1998.

5. Canale ST, Beaty JH. Benign/Aggressive Tumours of Bone: Campbell's Operative Orthopaedics. 11 ${ }^{\text {th }}$ edition. Philadelphia: Mosby, 2007.

6. Wold LE, Swee RG. Giant cell tumor of the small bones of the hand and feet. Semin Diagn Pathol 1984 1: 173-184.

7. Mechlin MB , Kricun ME,Stead J, Schwamm HA. Giant cell tumor of tarsal bones. Report of three cases and review of the literature. Skeletal Radiol 1984 11: 266-270.

8. Sharma S, Wani IH,Gupta N,Mahajan N,Salaria AQ: Giant cell tumor of talus: a case report. Cases Journal 2009 2:74

9. Campanacci M, Baldini N, Boriani S, Sudanese A. Giant-cell tumor of bone. JBJS 1987, 69A:106-114.

10. Campanacci M, Gluntini A, Olim R. Giant cell tumour of bone: A study of 209 cases with long term follow-up in 130 cases. Ital J Orthop Traumatol 1975 1:249-277.

11. Goldenberg RR, Campbell CJ, Bonfiglio M:Giant cell tumour: an analysis of 218 cases. JBJS 1970 52A: 619-664. 12. Sung HW, Kuo DP, Shu WP,Chai YB, Liu CC, Li SM. Giant cell tumour: an analysis of 208 cases in Chinese patients. JBJS 1982 64A: 755-761.

13.Bapat MR, Narlawar RS, Pimple MK, Bhosale PB. Giant cell tumour of talar body. J Postgrad Med 2000 46:110.

14. Dhillon MS,Singh B,Gill SS, Walker R,Nagi

ON. Management of giant cell tumor of the tarsal bones: a report of nine cases and a review of the literature. Foot Ankle 1993, 14(5): 265-272.

15. Malawer MM, Vance R. Giant cell tumour and aneurysmal bone cyst of the talus clinicopathological review and two case reports. J Foot Ankle 1981 1:235-44.

16. Sayed M N,Kondekar S, Jaiswal S, Rasalkar, Agrawal S. Giant cell tumor of talus, a case report of rare site. Euro J radiology Extra 2007 61(2): 73-75. 